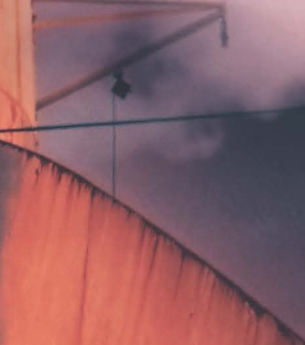

African perspectives on selected marine, maritime and

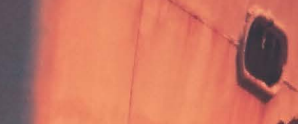

)
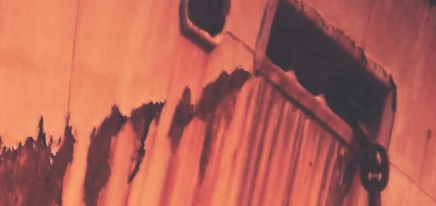

:

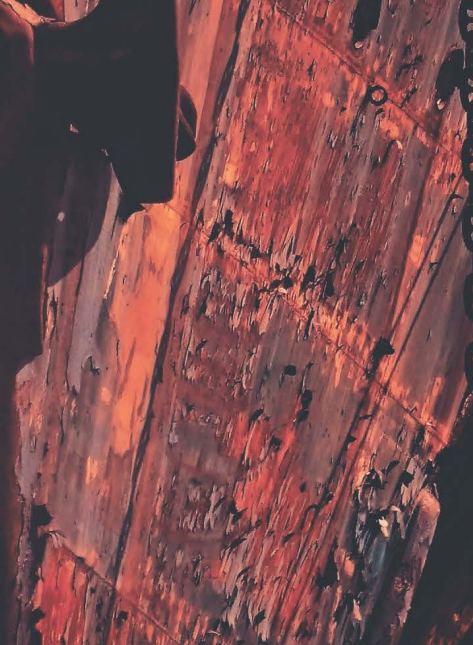

Patrick Vrancken \& Char! Hugo (Eds)

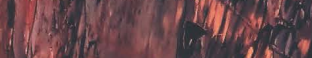

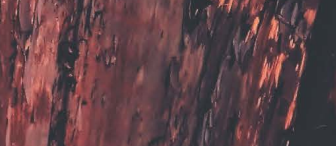
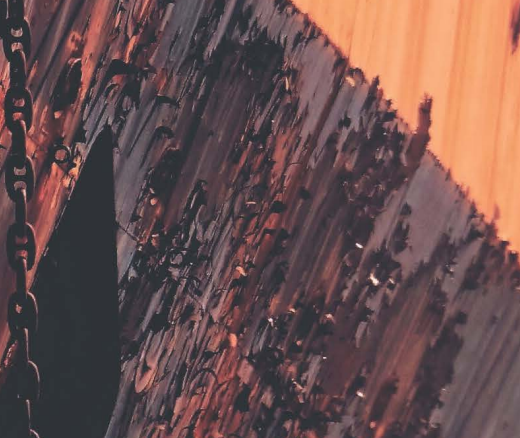
international trade law topics 


\title{
PORT STATE JURISDICTION IN TERMS OF ARTICLE 218 OF THE UN CONVENTION ON THE LAW OF SEA: A SOUTH AFRICAN PERSPECTIVE
}

\author{
DENNING METUGE*
}

PATRICK VRANCKEN ${ }^{\star \star}$

* Postdoctoral fellow, NRF Research Chair in the Law of the Sea and Development in Africa, Nelson Mandela University.

** Professor in Public Law and holder of the NRF Research Chair in the Law of the Sea and Development in Africa, Nelson Mandela University. 


\section{INTRODUCTION}

For centuries, two basic principles have characterised legal practice in the law of the sea: the right of the Coastal State to control the waters adjacent to its coast and the freedoms of navigation and fishing beyond the waters under the Coastal State's control. ${ }^{1}$ Though the subject of sporadic challenges for 300 years, the rules in respect of the freedoms of the high seas have long been accepted by all States as customary international law. ${ }^{2}$ Centre stage at the Third United Nations Conference on the Law of the Sea (UNCLOS III) was the need to find a compromise between the claims of many Coastal States over ever wider breadths of waters adjacent to their coasts and the opposition of many States to such extensive exercise of jurisdiction at the expense of the freedoms of the high seas. ${ }^{3}$ The result is the "new blue print for the partition of the seas" ${ }^{4}$ contained in the 1982 United Nations Convention on the Law of the Sea (LOSC). ${ }^{5}$ An innovation included in the LOSC is article $218,{ }^{6}$ which grants to the State in a port or offshore terminal of which a vessel finds itself, enforcement powers with regard to specific infringements of international environmental standards. ${ }^{7}$

This chapter does not aim to discuss the various views with regard to the scope of Port State jurisdiction. The goal is more limited in that the chapter merely aims to establish whether South Africa has the legislative arsenal to exercise Port State jurisdiction on the basis of the provisions of article 218 and, where necessary, to provide recommendations to amend the relevant legislative provisions in such a way as to incorporate the innovative powers conferred upon Port States by article 218 .

1 Sohn, Juras, Noyes and Franckx Law of the Sea in a Nutshell (2010) 1.

2 ibid 2.

3 Johnson Coastal State Regulation of International Shipping (2004) 2; Marten Port State Jurisdiction and the Regulation of International Merchant Shipping (2014) 1-2.

4 Gavouneli Functional Jurisdiction in the Law of the Sea (2007) 1.

51833 UNTS 3, (1982) 21 ILM 1261. Adopted: 10-12-1982; EIF: 16-11-1994.

6 König “Article 218” in Proelss (ed) United Nations Convention on The Law of The Sea: A Commentary (2017) 1489; Bang "Port State jurisdiction and article 218 of the UN Convention on the Law of Sea" 2009 Journal of Maritime Law \& Commerce (JMLC) 291 291-298; Nordquist, Rosenne and Yankov (eds) United Nations Convention on The Law of The Sea 1982: A Commentary (1991) IV 260.

7 See below. 
The following section provides a brief overview of State jurisdiction with regard to environmental matters at sea. Thereafter, the drafting history of article 218 will be explained and the content of the provision described. The extent to which South Africa has the legislative arsenal to exercise Port State jurisdiction on the basis of article 218 will then be established and recommendations aimed at filling existing gaps will be formulated.

\section{STATE JURISDICTION WITH REGARD TO ENVIRONMENTAL MATTERS AT SEA}

State jurisdiction is addressed in the LOSC under several categories: Flag State jurisdiction, Coastal State jurisdiction and Port State jurisdiction. ${ }^{8}$ In a few cases, there is also reference to a fourth category of State jurisdiction: the jurisdiction of the State of nationality. ${ }^{9}$ While the LOSC does not provide a definition of the terms "Flag State", "Coastal State" or "Port State", ${ }^{10}$ it lays out the scope of State authority in environmental matters at sea within the broader legal regime of each maritime zone. As far as the Coastal State is concerned, the LOSC states that it exercises varying degrees of jurisdiction over its internal waters, ${ }^{11}$ territorial sea, ${ }^{12}$ contiguous zone, ${ }^{13}$ exclusive economic zone (EEZ) ${ }^{14}$ and continental shelf. ${ }^{15}$ With regard to environmental regulation over its internal waters and territorial sea, the Coastal State may adopt laws and regulations for the preservation of its environment and "the prevention, reduction and control of pollution thereof". ${ }^{16}$ Over its EEZ, the Coastal State has jurisdiction with regard to the "protection and preservation of the marine environment" 17 and may adopt laws and regulations that give effect to generally accepted rules and standards for the prevention, reduction

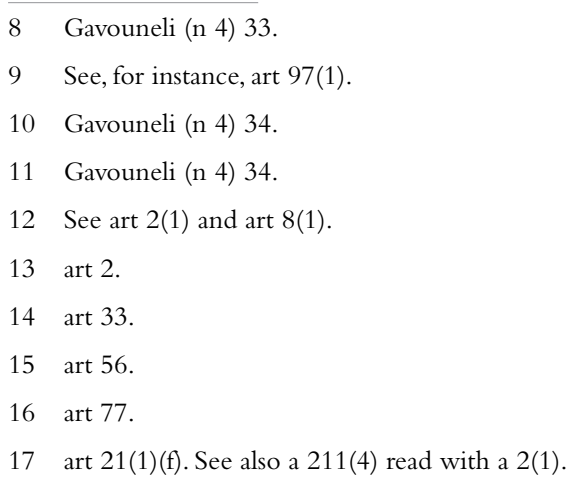


and control of pollution from vessels. ${ }^{18}$ Furthermore, in order to prevent pollution from vessels, the Coastal State may prevent a visiting foreign vessel within its port from sailing, where it has ascertained that the vessel is in violation of applicable international rules and standards relating to seaworthiness and, as a result, is a threat to the marine environment. ${ }^{19}$ In addition, the Coastal State may exercise enforcement jurisdiction against a visiting foreign vessel that has violated either its national laws pertaining to the prevention, reduction and control of pollution from vessels or applicable international rules and standards, when such a violation has occurred within the Coastal State's territorial sea or EEZ. ${ }^{20}$

Save in exceptional cases, ${ }^{21}$ the Flag State only has exclusive jurisdiction over the vessels flying its flag when they are on the high seas. ${ }^{22}$ Flag States have an obligation to take measures to ensure that, with regard to the vessels flying their flags, "the master, officers and, to the extent appropriate, the crew are fully conversant with and required to observe the applicable international regulations concerning the ... prevention, reduction and control of marine pollution...". 23

Moreover, the Flag State has an obligation to "cause an inquiry to be held by or before a suitably qualified person or persons into every marine casualty or incident of navigation on the high seas involving a ship flying its flag and causing ... serious damage to $\ldots$ the marine environment". ${ }^{24}$ In addition, the Flag States must ensure that vessels flying their flag or of their registry comply not only with applicable international rules and standards established through the competent international organisation or diplomatic conference, but also their national laws adopted in accordance with the LOSC for the prevention, reduction and control of pollution of the marine environment from vessels. ${ }^{25}$ Furthermore, the Flag States

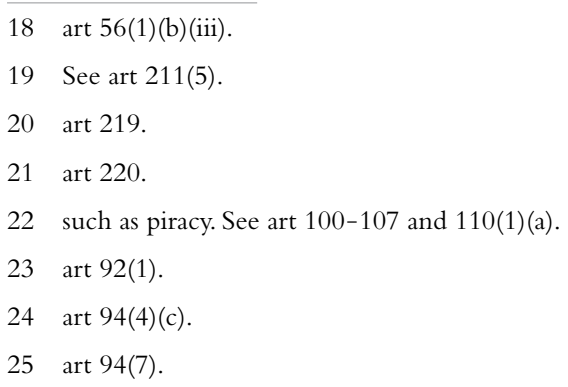


are obligated to effectively enforce the applicable rules, standards and regulations irrespective of where violations are committed. ${ }^{26}$

The term "Port State", which is distinguished from the terms "Coastal State" and "Flag State" in the preamble to the 1995 Agreement for the Implementation of the Provisions of the 1982 United Nations Convention on the Law of the Sea Relating to the Conservation and Management of Straddling Fish Stocks and Highly Migratory Fish Stocks, ${ }^{27}$ is only used in article 218 of the LOSC itself, where it refers to the State in a port or at an off-shore terminal of which a vessel finds itself.

\section{DRAFTING HISTORY OF ARTICLE 218}

Three factors in global maritime activity influenced the granting of jurisdiction to the Port State. ${ }^{28}$ The first factor relates to the fact that the jurisdiction of the Flag State over the vessels flying its flag is, as already stated, exclusive on the high seas. This means that, when the Flag State does not comply with its duty to "effectively exercise its jurisdiction and control in administrative, technical and social matters over [the] ships flying its flag" 29 - which is often the case of the so-called "flags of convenience",$-{ }^{30}$ no action may be taken by other States while the vessels exercise the freedom of navigation. The second factor is the adoption by the IMO of instruments relating to safety and environmental protection, such as the 1974 International Convention for the Safety of Life at Sea, as amended (SOLAS), ${ }^{31}$ the 1973 International Convention for the Prevention of Pollution from Ships (MARPOL) ${ }^{32}$ and the 1978 International Convention on Standards of Training, Certification and Watchkeeping for Seafarers, as amended (STCW), ${ }^{33}$ which allow Port States to inspect visiting

26 art 211(2) and 217(1).

27 art 217(1).

282167 UNTS 88, (1995) 34 ILM 1542, (1995) 29 LOSB 25. Adopted: 04-12-1995; EIF: 11-12-2001.

29 Marten (n 3) 42.

30 art 91(1) of the LOSC.

31 Gross "Safety in sea transport” 1994 Journal of Transport Economics and Policy 99101.

321184 UNTS 1, (1975) 14 ILM 959. Adopted: 01-11-1974; EIF: 25-05-1980.

331340 UNTS 184, (1973) 12 ILM 1319. Adopted: 02-11-1973; EIF: 10-02-1983. 
vessels. ${ }^{34}$ The third factor is the increase in the number of significant oil spills such as that of the Torrey Canyon in $1967^{35}$ and the Amoco Cadiz disaster in 1978, which prompted European States to convene in Paris and adopt the 1982 Paris Memorandum of Understanding on Port State Control (Paris MoU). ${ }^{36}$ Under the latter, twenty-seven maritime authorities have agreed to undertake a harmonised set of Port State control (PSC) procedures in the North Atlantic basin from North America to Europe. ${ }^{37}$

As a matter of principle, Port States have always had the authority to deny or impose conditions for entry into their ports and other internal waters. ${ }^{38}$ During the MARPOL negotiations, an attempt was made to not only increase the authority of the Port States by allowing them to exercise Port State control - that is to say the limited executive jurisdiction of the Port State to inspect documents evidencing compliance with generally accepted standards, to perform administrative duties such as the detention of ships until they are seaworthy and to order vessels to proceed to the nearest repair yard ${ }^{39}$ - but also Port State jurisdiction, a wider authority that includes penalising and instituting proceedings regarding conduct by foreign vessels outside of the Port State's national jurisdiction. ${ }^{40}$ That attempt failed and a

341361 UNTS 2. Adopted: 07-07-1978; EIF: 28-04-1984.

35 Bang "Is port State control an effective means to combat vessel-source pollution? An empirical survey of the practical exercise by port States of their powers of control" 2008 International Journal of Marine and Coastal Law 715 719. See also regs I/ 6 and 19 SOLAS; art X of STCW and art 5(2) of MARPOL.

36 See, for instance, Rares "Ships that changed the law: The Torrey Canyon disaster" 2018 Lloyd's Maritime and Commercial Law Quarterly 336 336-347.

37 See Paris MoU on Port State Control “A short history of the Paris Mou on PSC” (2019) https://www.parismou. org/about-us/history (07-05-2020).

38 See clause 9.2 Paris MoU. Since then, the IMO has facilitated the adoption of eight other regional memoranda on Port State control based on the Paris MOU model: the 1992Viña del Mar Agreement between the maritime administrations of the Coastal States of South America http://www.marine-centre.org/Docs/MOU/LATIN_ AMERICA_MOU.pdf (07-05-2020); the 1993 Tokyo Memorandum between the administrations of the Coastal States of the Asia-Pacific region http://www.tokyo-mou.org/organization/memorandum_of_understanding.php (07-05-2020]); the 1996 Caribbean Memorandum http://www.caribbeanmou.org/sites/default/files/Approved_ MOU_Rev_7_Jan_2018.pdf (07-05-2020); the 1997 Mediterranean Memorandum https://iea.uoregon.edu/treatytext/1997-mediterraneanmemorandumunderstandingportstatecontrolentxt (07-05-2020); the 1998 Indian Ocean Memorandum (available at http://www.iomou.org/moumain.htm (07-05-2020); the 1999 Memorandum for the Western and Central Regions of Africa http://www.abujamou.org/index.php?pid=5t77uyggfgdf6756 (07-05-2020); the 2000 Black Sea Memorandum http://www.marine-centre.org/Docs/MOU/BLACK_SEA_MOU.pdf (07-052020); and the 2004 Persian Gulf Memorandum https://www.riyadhmou.org/aboutmoutext.html (07-05-2020).

39 See, for instance, Bang (n 6) 293-294; Bodansky "Protecting the marine environment from vessel-source pollution: UNCLOS III and beyond” 1991 Ecology Law Quarterly 719 719-759 and Legatski “Port State jurisdiction over vessel-source marine pollution” 1977 Harvard Environmental Law Review 448461.

40 Bang "Recommendations for policies on port State control and port State jurisdiction" 2013 JMLC 115119. 
decision as to whether and to what extent the jurisdiction of Flag States should be supplemented by Port State jurisdiction was left to be made during the negotiating process at UNCLOS III. ${ }^{41}$

\begin{abstract}
"In the early days of the negotiations, flag States, coastal States and some environmentally-friendly industrialised States pursued opposing interests with regard to port State jurisdiction. Whereas traditional flag States wanted to retain exclusive jurisdiction with limited inspection rights for port States and coastal States focussed on extensive enforcement rights in the EEZ, some industrialised States, such as Canada, the Netherlands and the United States, submitted proposals at the 1973 session of the Seabed Committee on far-reaching enforcement competencies for port States". ${ }^{42}$
\end{abstract}

The first version of the provisions that became article 218 appeared in the 1975 Informal Single Negotiating Text (ISNT) ${ }^{43}$ as articles 27 and 28, provisions of which were merged in the 1976 Revised Single Negotiating Text (RSNT) ${ }^{44}$ into article 28, which became article 219 of the 1977 Informal Composite Negotiating Text $(\mathrm{ICNT})^{45}$ and article 218 from the 1979 revised version of Informal Composite Negotiating Text (ICNT-Rev 1$)^{46}$ onwards. Initially, no distinction was made between Coastal States and Port States. ${ }^{47}$ The term "Port State" was used for the first time in article 28(4) of the RSNT - where it became clear that the Port State is "the State that acts with regard to violations occurring outside the maritime zones under its own jurisdiction" 48 - and the term was later used in the titles of article 219 of the ICNT and article 218 thereafter. However, the geographical scope of the events concerned was only changed from "regardless of where the violation occurred" 49 to "outside the internal waters, territorial sea or exclusive economic zone of" the Port State in article 219 of the ICNT. By contrast, while article 27(3) of the ISNT limited the geographical scope of the events with regard

\footnotetext{
41 On the distinction between Port State control and Port State jurisdiction, see further Bang (n 39) 119-120.

42 König (n 6) 1490-1491.

43 ibid 1491.

44 Part III of UN Doc A/CONF.62/WP.8/Part III (1975).

45 UN Doc A/CONF.62/WP.8/REV.1/PART II (1976).

46 UN Doc A/CONF.62/WP.10 (1977).

47 UN Doc A/CONF.62/WP.10/Rev.1 (1979).

48 See art 27 of the ISNT.

49 König (n 6) 1491.
} 
to which proceedings could be instituted, to the yet-to-be determined maritime domain of the Coastal State, that scope was already extended beyond the outer limit of the EEZ in article 28(1) of the RSNT. ${ }^{50}$

Initially, a distinction was only made between discharge violations and other infringements of international rules and standards with regard to the institution of proceedings. ${ }^{51}$ In other words, the provisions relating to investigations applied for all infringements. ${ }^{52}$ That power was quickly limited to discharges in article 28(1) of the RSNT, which also replaced the very general phrase "international rules and standards" with "international rules and standards established through the competent international organization or general diplomatic conference" ${ }^{33}$ At the same time, the investigations which were initially mandatory ${ }^{54}$ became optional. ${ }^{55}$

Neither article 27 nor article 28 of the ISNT took into account that the Port State requires the consent of another Coastal State in which the discharge took place, that of the Flag State or that of a State damaged or threatened by the discharge before instituting proceedings with regard to that discharge, unless the discharge caused, or is likely to cause, pollution in the waters of the Port State. Such a requirement was already confirmed in article 28(2) of the RSNT and is now stated in article 218(2) of the LOSC. By contrast, the ISNT already dealt with the records of investigations. Article 28(4) compelled the Port State to always forward the relevant reports to the Flag State. This provision was amended in article 28(4) of the RSNT in such a way that the transmission of those records was now optional and at the request of the Coastal State concerned. It became mandatory again and also at the request of the Flag State in article 219(4) of the ICNT. Similarly, the issue of requests by other States to investigate was already addressed in article 28(2) of the ISNT, which stated that it was not mandatory for the Port State to comply with such requests. Article 28(3) of the RSNT provided

50 See art 27(1) of the ISNT. The wording used in a 28(1) of the RSNT is "irrespective of the where the violation occurred".

51 Compare with art 27(3) of the ISNT.

52 Compare art 27(1) and (3) of the ISNT.

53 See art 27(1)(a) of the ISNT.

54 The word "applicable" was added at the beginning of the phrase in article 219 of the ICNT.

55 See art 27(1) of the ISNT. 
that the Port State had to "endeavour to comply" and, since article 219(3) of the ICNT, the provision reads: "shall, as far as practicable comply".

\section{Article 218 of the LOSC now reads as follows:}

" 1 . When a vessel is voluntarily within a port or at an off-shore terminal of a State, that State may undertake investigations and, where the evidence so warrants, institute proceedings in respect of any discharge from that vessel outside the internal waters, territorial sea or exclusive economic zone of that State in violation of applicable international rules and standards established through the competent international organization or general diplomatic conference.

2. No proceedings pursuant to paragraph 1 shall be instituted in respect of a discharge violation in the internal waters, territorial sea or exclusive economic zone of another State unless requested by that State, the flag State, or a State damaged or threatened by the discharge violation, or unless the violation has caused or is likely to cause pollution in the internal waters, territorial sea or exclusive economic zone of the State instituting the proceedings.

3. When a vessel is voluntarily within a port or at an off-shore terminal of a State, that State shall, as far as practicable, comply with requests from any State for investigation of a discharge violation referred to in paragraph 1, believed to have occurred in, caused, or threatened damage to the internal waters, territorial sea or exclusive economic zone of the requesting State. It shall likewise, as far as practicable, comply with requests from the flag State for investigation of such a violation, irrespective of where the violation occurred.

4.The records of the investigation carried out by a port State pursuant to this article shall be transmitted upon request to the flag State or to the coastal State. Any proceedings instituted by the port State on the basis of such an investigation may, subject to section 7 , be suspended at the request of the coastal State when the violation has occurred within its internal waters, territorial sea or exclusive economic zone.The evidence and records of the case, together with any bond or other financial security posted with the authorities of the port State, shall in that event be transmitted to the coastal State. Such transmittal shall preclude the continuation of proceedings in the port State". 


\section{INTERPRETATION OF ARTICLE 218}

The scope of application of article 218 is clear in that it confers Port State jurisdiction over a vessel that is voluntarily within one of the State's ports or at one of its off-shore terminals "in respect of any discharge from that vessel outside the internal waters, territorial sea or exclusive economic zone of th[e] State in violation of applicable international rules and standards established through the competent international organization or general diplomatic conference". ${ }^{56}$ The conferring of enforcement jurisdiction to Coastal States in such a case is not problematical.

Indeed, when a vessel is within a port or at an off-shore terminal of a Coastal State, that vessel is within the maritime territory of that State ${ }^{57}$ and, therefore, under the latter's exclusive executive authority, an authority that may be used to enforce the provisions of the civil and criminal legislation of that State..$^{58} \mathrm{~A}$ confusion may arise in that the Coastal State exercises the same exclusive executive authority in the exercise of its Coastal State jurisdiction as it does in the exercise of its Port State jurisdiction. This explains why the term "Port State" is often employed to refer to a Coastal State both when it exercises its Coastal State jurisdiction and when it exercises its Port State jurisdiction..$^{59}$ However, as far as State ocean jurisdiction is concerned, "[a] port State is always a coastal State - although the reverse is not always true". ${ }^{60}$ As indicated above, the drafters of the LOSC were clearly aware of this when the geographical scope of the events over which Port State jurisdiction may be exercised in terms of article 218 was changed from "regardless of where the violation occurred" or exclusive economic zone of" the Port State, that is to say outside the maritime zones over which the Coastal State exercises Coastal State jurisdiction. ${ }^{62}$ It is in

\footnotetext{
56 See art 28(1) of the RSNT.

57 art 218(1).

58 See art 2, 8 and 12 of the LOSC.

59 See, for instance, Johnson (n 3) 44; Marten (n 3) 9; Molenaar "Port State jurisdiction:Towards mandatory and comprehensive use" in Freestone, Barnes and Ong (eds) The Law of the Sea (2006) 192194.

60 See, for example, Molenaar (n 58) 193-194; Marten (n 3) 3; König "The enforcement of the international law of the sea by coastal and port States" 2002 Zeitschrift für ausländisches öffentliches Recht und Völkerrecht 5.

61 Gavouneli (n 4) 44.

62 See art 27(1) of the ISNT.
} 
the exercise of the latter that the Coastal State has been conferred enforcement powers under the provisions of IMO instruments such as SOLAS and MARPOL. Indeed, those instruments only confer Coastal State jurisdiction to Coastal States over matters arising within their internal waters, territorial seas and EEZs. As far as SOLAS is concerned, a Coastal State may take corrective measures against a ship in its port if, subsequent to a survey, it is "determine[d] that the condition of the ship or its equipment does not correspond substantially with the particulars of the certificate or is such that the ship is not fit to proceed to sea without danger to the ship...". ${ }^{63}$ Similarly, MARPOL specifically authorises a State party to prohibit and impose sanctions for the violations of its terms within the jurisdiction of the party in question. ${ }^{64}$ The Port State, on the other hand, does not protect its own interests, but those of another State or, with regard to the high seas, the interest of all States. In this sense, the main distinction between the Coastal States' exercise of their Coastal State jurisdiction and their exercise of their Port State jurisdiction, is the functions they fulfil in the process. ${ }^{65}$

"[C]onsiderations of the rule of law suggest that a port State should not prosecute under Article 218 for discharge violations by foreign ships on the high seas unless it has first made such acts criminal offences under its own law". ${ }^{66}$ However, article 218(1) makes reference to violations of "applicable international rules and standards", meaning that the Port State may not adopt domestic discharge standards applicable outside its maritime domain which are inconsistent with those internationally recognised rules and standards. ${ }^{67}$ The main international instrument regulating discharge violations by vessels at sea is MARPOL.$^{68}$ While, as already indicated, the Coastal State may only apply MARPOL up to the outer limit of the EEZ when it exercises its Coastal State jurisdiction, article 218 is to the effect that the Coastal State may apply MARPOL with regard to discharges taking place

63 See art 219 of the ICNT.

64 See reg I/6(c) of SOLAS.

65 See art 4(2) of MARPOL. See further section 5 below.

66 See König (n 6) 1490.

67 Bang (n 6) 310.

68 McDorman "Port State enforcement: A comment on article 218 of the 1982 Law of the Sea Convention" 1997 JMLC 305 316. See also Bodansky (n 38) 762-763. 
on the high seas when it exercises its Port State jurisdiction. This is in addition to the application of MARPOL by the Flag States, in the exercise of their Flag State jurisdiction, over discharges on the high seas by vessels flying their flags. ${ }^{69}$

State practice shows that some States have adopted domestic legislation giving effect to the provision of article 218, either in full or in part. For instance, article 1.10.07 of the Malagasy Maritime Code $^{70}$ is an example of a partial incorporation of article 218 when it provides that the "State may institute proceedings in respect of discharges outside its exclusive economic zone if such discharges give rise or may give rise to pollution of its own internal waters, its own territorial sea or its own exclusive economic zone". Indeed, the article incorporates article 218(1) to a limited extent because it does not empower the Malagasy State to institute proceedings in respect of discharges on the high seas that do not have an impact on the Malagasy maritime domain. In addition, article 218(4) is not incorporated at all. By contrast, article 1.10.07 incorporates fully article 218(3) when it provides that " $[t]$ he Malagasy State shall make every possible attempt to accede to requests from any State for investigation concerning discharges that allegedly occurred within the maritime domain of the requesting State". Bulgaria has also adopted legislation giving effect to Port State jurisdiction, but only as far as article 218(3) is concerned. ${ }^{71}$ In that regard, the ambit of article $218(3)$ is both limited - in that the State is expected to provide legal assistance on the basis of reciprocity when the Requesting State is not a EU member - and extended - in that legal assistance is to be provided irrespective of whether it is practicable to do so.

Because article 218(1) provides for Port State jurisdiction only as an optional measure rather than an obligation, ${ }^{72}$ States do not violate the provision when they do not make use of their powers either because they do not have sufficient means to do so or because they elect not to act against foreign vessels for various reasons, such as gaining a competitive advantage or safeguarding port activities

69 Bodansky (n 38) 729.

70 See art 3(1) MARPOL.

71 See Loi n99-028 du 3 février 2000 portant refonte du Code maritime http://www.droit-afrique.com/upload/doc/ madagascar/Madagascar-Code-1999-maritime.pdf (07-05-2020) (own translation).

72 See art 55 of the Space, Inland Waterways and Ports Act of Bulgaria of 28 January 2000 http://www.conces. government.bg/save?fileId=3310\&type $=$ doc\&fileName=Maritime_Space_Inland_Waterways.pdf (07-05-2020). For more examples, see also Bang (n 6) 303-309. 
that are a source of economic growth for the State. ${ }^{73}$ In other words, the optional character of Port State jurisdiction in terms of article 218(1)-(2) means that the latter does little to prevent States succumbing to the temptation of becoming "ports of convenience" in order to boost their economy or ensure the unimpeded entry of certain imported goods.

\section{INCORPORATION OF ARTICLE 218 IN SOUTH AFRICAN LAW}

Article 218 is the basis for Port State jurisdiction as a measure to regulate environment-related navigational standards. In accordance with that provision, South Africa may enact legislation to the effect that, when a vessel is voluntarily within one of its ports or off-shore terminals, it may exercise the executive and adjudicative Port State jurisdiction to investigate and,

"where the evidence so warrants, institute proceedings in respect of any discharge from that vessel outside the internal waters, territorial sea or exclusive economic zone of [South Africa] in violation of applicable international rules and standards established through the competent international organization or general diplomatic conference". ${ }^{74}$

As indicated earlier, the "applicable international rules and standards" are contained in MARPOL which, as amended by its 1978 Protocol (MARPOL 1973/1978), came into force in South Africa in $1985 .{ }^{75}$ The South African Maritime Safety Authority (SAMSA) is vested with the power to enforce the provisions of MARPOL, to which the Marine Pollution (Prevention of Pollution from Ships) Act (PPSA $)^{76}$ gives effect in relation to all South African vessels wherever they may $\mathrm{be}^{77}$ as well as to any other vessels while they are in South African internal waters, territorial sea or EEZ. ${ }^{78}$ To that extent and as a party to MARPOL, South Africa

73 Gavouneli (n 4) 45.

74 Molenaar (n 60) 193.

75 art 218(1).

76 South Africa acceded to AnnexV in 1992, Annex III in 1997, Annex IV in 2015 and Annex VI in 2015 (see IMO Status of IMO Instruments (2020) 114).

772 of 1986. In terms of s 2(2)(b) read with s 1 of the PPSA, “[u]nless the context indicates otherwise, a reference in the Convention... to the Administration or Government shall, in relation to a South African ship or the Republic, be construed as, or as including, a reference to the [SAMSA] or any person acting on its authority".

78 s $2(1)(a)$. 
has an obligation to implement its provisions and annexes to prevent the pollution of the marine environment by the discharge of harmful substances, or effluents containing such substances, in contravention of MARPOL. ${ }^{79}$

In contrast to article 218(1) that allows the Port State to institute proceedings where a discharge in violation of MARPOL has occurred outside the internal waters, territorial sea and EEZ of the State, MARPOL only requires South Africa to enact law prohibiting and sanctioning any violation of its standards within South Africa's maritime domain. ${ }^{80}$ Indeed, with regard to foreign visiting vessels, the wording of section 2(1)(b) of the PPSA has the effect of limiting South Africa's application of MARPOL to the conduct of visiting vessels within the maritime zones that are subject to South Africa's jurisdiction. ${ }^{81}$ In other words, the PPSA does not provide for the institution of proceedings in accordance with article 218(1) against visiting vessels that enter a South African port after committing a discharge violation on the high seas. For South Africa to be able to give effect to the provisions of article 218(1), the PPSA will have to be amended to include a provision that specifically extends its scope to visiting vessels that enter a South African port or offshore terminal after committing a discharge in violation of MARPOL on the high seas. ${ }^{82}$

As indicated earlier, South Africa is prohibited, in terms of article 218(2), from commencing any proceedings in terms of article 218(1) where the discharge violation occurred in
"the internal waters, territorial sea or exclusive economic zone of another State unless requested by that State, the flag State, or a State damaged or threatened by the discharge violation, or unless the violation has caused or is likely to cause pollution in the internal waters, territorial sea or exclusive economic zone of [South Africa]".

79 s 2(1)(b). In terms of art 3(1) of MARPOL, the foreign vessels to which the provisions of the PPSA apply are those registered under the flag of a party to MARPOL or operating under the authority of such a party. See also Vrancken "South Africa" in Vrancken and Tsamenyi (eds) The Law of the Sea:The African Union and its Member States (2018) 696. In terms of a draft Marine Pollution (Prevention of Pollution from Ships) Amendment Bill, 2019, the PPSA would be amended in such a way as to give effect in South African law to Annex IV and Annex VI (GN 476 in GG 42688 of 06-09-2019).

80 s 2(2) of the PPSA read with a 1(1) of MARPOL.

81 See art 4(2)-(4) of MARPOL. See also Bang (n 6) 294.

82 Moreover, the wide wording of s 2(1)(b) conflicts with the limitation in art 3 of MARPOL. See furtherVrancken South Africa and the Law of the Sea (2011) 369-370. 
Once again, the PPSA does not provide for the institution of proceedings in accordance with article 218(2) against visiting vessels that enter a South African port after committing a discharge violation in the internal waters, territorial sea or EEZ of another State. For South Africa to be able to give effect to the provisions of article 218(2), the PPSA will have to be amended to include, in addition to a provision giving effect to article 218(1), a provision that stipulates that, when a visiting vessel enters a South African port or offshore terminal after committing a discharge violation in the maritime domain of another State, South Africa will not institute any proceedings unless: (a) requested to do so by the State in the maritime domain of which the discharge took place, the Flag State or a State damaged or threatened by the discharge violation; or (b) the violation has caused or is likely to cause pollution in the South African maritime domain.

Moreover, in terms of article 218(3),

"[w]hen a vessel is voluntarily within a port or at an off-shore terminal of a State, that State shall, as far as practicable, comply with requests from any State for investigation of a discharge violation referred to in paragraph 1, believed to have occurred in, caused, or threatened damage to the internal waters, territorial sea or exclusive economic zone of the requesting State. It shall likewise, as far as practicable, comply with requests from the flag State for investigation of such a violation, irrespective of where the violation occurred".

\title{
MARPOL confirms that South Africa
}

\begin{abstract}
"may inspect a ship to which [MARPOL] applies when it enters the ports or offshore terminals under its jurisdiction, if a request for an investigation is received from any Party together with sufficient evidence that the ship has discharged harmful substances or effluents containing such substances in any place". ${ }^{83}$
\end{abstract}

However, in contrast to the mandatory character of article 218(3), compliance with a request for investigation in terms of MARPOL is optional. Moreover, article 218(3) does not require the Requesting State to provide "sufficient evidence" of a discharge violation by the vessel, but only requires that the Requesting State "believe" that a discharge violation as provided in article 218(1) has occurred.This

83 The amended provision will have to make it clear that the visiting vessels in question are only those flying the flag of a State party to MARPOL or operating under the authority of a party to MARPOL. 
means that, for South Africa to be able to give effect to the provisions of article 218(3), the PPSA will have to be amended to include, in addition to provisions giving effect to article 218(1) and (2), a provision that stipulates that: (a) when South Africa receives a request for investigation of a discharge violation believed to have occurred in, caused, or threatened damage to the internal waters, territorial sea or EEZ of the Requesting State, that request must be investigated irrespective of whether sufficient evidence has been provided by the Requesting State; and (b) when South Africa receives a request from a Flag State for investigation of a discharge violation wherever it occurred, that request must, as far as practicable, be complied with.

As far as it is concerned, article 218(4) requires that any records of an investigation undertaken by the South African authorities pursuant to article 218 be transmitted upon request to the Flag or Coastal State. This requirement is mirrored in MARPOL when it provides that, where South Africa has elected to comply with the request for an investigation into a discharge violation, it must provide the report of its investigation to the Requesting State so that appropriate action can be taken in conformity with the Convention. ${ }^{84}$ Article $218(4)$ also provides that proceedings instituted by South Africa on the basis of an investigation undertaken pursuant to article 218 may, subject to a number of safeguards, ${ }^{85}$ be suspended at the request of a Coastal State when the violation has occurred within that State's internal waters, territorial sea or EEZ. Moreover, any "evidence and records of the case, together with any bond or other financial security posted with [SAMSA] shall in that event be transmitted to the coastal State", such a transmittal precluding the continuation of proceedings in South Africa. As earlier mentioned, the PPSA and MARPOL do not require that any proceedings to be undertaken in relation to a discharge violation that occurred outside South Africa's maritime domain. It is therefore not surprising that they do not contain any suspension-of-proceedings provisions that mirror those of in article 218(4), nor any provisions requiring that any bond or other financial security posted with SAMSA be transferred to the

84 See art 6(5) of MARPOL.

85 ibid. 
Coastal State. Once again, the PPSA will have to be amended to give effect to the provisions of article 218(4).

\section{CONCLUSION}

Ports are within the territory of a Coastal State and, for that reason, that State may exercise, within its ports, both its Coastal State jurisdiction and its Port State jurisdiction. Coastal State jurisdiction, however, does not extend to discharge violations that occurred outside the State's internal waters, territorial sea or EEZ. The innovative character of Port State jurisdiction in terms of article 218 is that it provides a basis for the Coastal State to exercise its jurisdiction and institute proceedings against visiting vessels that are within one of its ports or offshore terminals with regard to discharge violations outside its internal waters, territorial sea or EEZ. However, in order for the relevant organs of the Coastal State to be able to exercise Port State jurisdiction, the provisions of article 218 need to be accurately and comprehensively incorporated into domestic law. The incorporation of MARPOL into South African domestic law by the PPSA does not do so because the Act as it stands only provides for the application of MARPOL by South Africa in the exercise of either its Coastal State jurisdiction or its Flag State jurisdiction. In order to address this issue and ensure that South Africa's ports are not safe havens for vessels from which illegal discharges have occurred outside the country's maritime domain, it is submitted, on the basis of the above discussion, that a suitable course of action would be to amend the PPSA as follows:

\section{The insertion of the following definition in section 1:}

"Convention on the Law of the Sea" means the United Nations Convention on the Law of the Sea adopted by the Third United Nations Conference on the Law of the Sea in Kingston on 10 December 1982. 


\section{The amendment of section $2(1)$ as follows: ${ }^{86}$}

Subject to the provisions of this Act, the Convention shall have effect in relation to:

(a) any South African ship, wherever it may be; [and]

(b) any other ship while it is in the Republic or its territorial waters or exclusive economic zone: and

(c) any other ship while it is outside the Republic or its territorial waters or exclusive economic zone in the cases where the Republic has jurisdiction in terms of section $2 \mathrm{~A}$.

The text in bold to be deleted and the underlined text to be inserted.

\section{The insertion of a new section $2 \mathrm{~A}$, which reads as follows:}

(1) When a ship other than a South African ship and flying the flag of a State party to the Convention on the Law of the Sea is voluntarily within a port or at an offshore terminal of the Republic, the Authority may undertake investigations and, where the evidence so warrants, proceedings may be instituted in respect of any discharge from that ship outside the internal waters, territorial sea or exclusive economic zone of the Republic in violation of applicable international rules and standards established through a competent international organization or general diplomatic conference, including those contained in the Convention.

(2) No proceedings pursuant to subsection 1 shall be instituted in respect of a discharge violation in the internal waters, territorial sea or exclusive economic zone of another State unless -

(a) requested by that State, the Flag State or a State damaged or threatened by the discharge violation; or

(b) the violation has caused or is likely to cause pollution in the internal waters, territorial sea or exclusive economic zone of the Republic.

(3) When a ship other than a South African ship and flying the flag of a State party to the Convention on the Law of the Sea is voluntarily within a port or at an off-shore terminal of the Republic, the Authority shall, as far as practicable, comply with requests from any State party to the Convention on the Law of the Sea for investigation of a discharge violation referred to in subsection 1, believed to have occurred in, caused, or

86 See art 223-233 of the LOSC. 
threatened damage to the internal waters, territorial sea or exclusive economic zone of the Requesting State. It shall likewise, as far as practicable, comply with requests from a Flag State for investigation of such a violation, irrespective of where the violation occurred.

(4) The records of the investigation carried out by the Authority pursuant to this section shall be transmitted upon request to the Flag State or to the Coastal State. Any proceedings instituted in the Republic on the basis of such an investigation may, subject to articles 223 to 233 of the Convention on the Law of the Sea, be suspended at the request of a Coastal State when the violation has occurred within its internal waters, territorial sea or exclusive economic zone. The evidence and records of the case, together with any bond or other financial security posted in the Republic, shall in that event be transmitted to the Coastal State. Such transmittal shall preclude the continuation of proceedings in the Republic. 